\title{
Major and Trace Element Contamination of Short-Term Snow Cover During and After a Dust Storm and Analysis by ICP-OES
}

\author{
Osman Akba, Ersin Kilinc, Isil Aydin, Sait Erdogan, Firat Aydin*, M. Zahir Duz, \\ and Candan Hamamci \\ Dicle University, Science Faculty, Chemistry Department, 21280 Diyarbakir, Turkey
}

\section{INTRODUCTION}

One of the reasons for chemical contamination is atmospheric pollution. It has been reported that organic and inorganic toxic chemicals can accumulate in topsoil from atmospheric deposition by sedimentation, impaction, and interception (1). The process of identification and quantification of pollutants to their sources is an important step in air quality management $(2,3)$. Residence time and mobility of pollutants depend on meteorological conditions, such as wind speed and precipitation, which affect dry and wet deposition, respectively $(4,5)$. The World Health Organization (WHO) has focused on air pollution and health and periodically publishes recommended guidelines that would adequately protect public health (6).

Trace metals influence the toxicity of air-borne particulate matter (7-9). Some heavy metals (Mn, V, $\mathrm{Cr}, \mathrm{Ni}, \mathrm{Cu}$, and $\mathrm{Zn}$ ) play an important role in the nutrition of plants, animals, and humans, but if they occur in excess, they may produce toxic effects. Elements such as Cd, $\mathrm{Hg}$, and $\mathrm{Pb}$ are toxic even at very low conentrations. Metals are redox active and can, therefore, induce or catalyze chemical change leading to the production of free radicals, which are known to cause tissue inflammation $(10,11)$.

Recent environmental studies have been devoted to analyzing snow in order to establish the concentration of organic and inorganic

\footnotetext{
*Corresponding autbor.

E-mail: : faydin@dicle.edu.tr

Tel: +90412248 8001 (Ext. 3086)

Fax: +904122488300
}

\begin{abstract}
The levels of major and trace elements are key data for evaluating the toxicity of potential particulate matter and for identifying pollution sources. From this point of view, snow is considered an ideal matrix to observe deposition from the atmosphere due to environmental and anthropogenic activities. This work has demonstrated that major and trace element levels of $\mathrm{Al}, \mathrm{As}, \mathrm{Cd}, \mathrm{Co}, \mathrm{Cr}, \mathrm{Cu}, \mathrm{Fe}, \mathrm{Mn}$, $\mathrm{Mo}, \mathrm{Ni}, \mathrm{Pb}, \mathrm{Sb}, \mathrm{Se}, \mathrm{Sn}$, and $\mathrm{Zn}$ were found in snow precipitation sampled during and after a dust storm in and around Diyarbakir city, SE Anatolia, Turkey. A simple methodological approach consisting of surface snow sampling and analysis by ICP-OES provides information about the spatial distribution and temporal evolution of atmospheric precipitation. The concentrations of toxic metals were found at high levels and are therefore a threat to human health. In particular, the concentrations for Fe and Al were significantly higher than for the other elements.
\end{abstract}

pollutants and their chemical composition and thus to protect the health of the population (12). Snow is one of the important indicators of pollution by observing deposition of matter from the atmosphere $(13,14)$. Industrial and anthropogenic activities are the main sources that cause organic and inorganic pollution. It has been reported that atmospheric particulates containing trapped pollutants in snow are diluted by pure water rather than by other earth materials and the composition of atmospheric deposition can be unambiguously measured down to very low concentrations (15). It has also been reported that snow can store scavenged species and later liberate the accumulated species into the atmosphere (16). Pollutants trapped in melting snow could easily be released and trapped in aerosol and particles which would spread through the environment. Reports have been published on urban aerosol elemental profiles which provide information for particular city locations or other populated areas such as Cerro Colorado and Nevados de Chillian (Chile) $(15,17)$.

The concentrations of $\mathrm{V}, \mathrm{Cr}, \mathrm{Mn}$, $\mathrm{Cu}, \mathrm{Zn}, \mathrm{Co}, \mathrm{Ag}, \mathrm{Cd}, \mathrm{Ba}, \mathrm{Pb}, \mathrm{Bi}$, and $\mathrm{U}$ in Antarctic snow from Coats Land have been recorded since the mid-19th to the late-20th century by sector field inductively coupled plasma mass spectrometry (SF-ICPMS). The concentrations were found to be extremely low (at pg/g levels) for most metals, thus confirming the high purity of Antarctic snow $(18,19)$. For $\mathrm{Mn}, \mathrm{Co}, \mathrm{Ba}$, and possibly $\mathrm{V}$ and $\mathrm{Cd}$, no clear time trends have been recorded. For $\mathrm{Cr}$, $\mathrm{Cu}, \mathrm{Zn}, \mathrm{Ag}, \mathrm{Pb}, \mathrm{Bi}$, and $\mathrm{U}$, on the other hand, a pronounced increase in concentrations has been observed during recent decades. Planchon et al. (18) reported that historical changes in metal concentrations can be attributed to emission of heavy metals to the atmosphere originating from human activities in South America, Southern Africa, and Australia, especially from nonferrous metal mining and smelting operations in Chile and Peru, Zaire and Zambia, and Australia. Elemental concentrations (especially for 
heavy metals) in snow collected from Mt. Qomolangma, Tibet, were found at the levels of $0.695 \mathrm{ng} / \mathrm{g}$ for $\mathrm{Cu}, 15.34 \mathrm{ng} / \mathrm{g}$ for Fe, $2.94 \mathrm{ng} / \mathrm{g}$ for $\mathrm{Mn}, 3.25 \mathrm{ng} / \mathrm{g}$ for $\mathrm{Zn}, 0.141 \mathrm{ng} / \mathrm{g}$ for As, $3.429 \mathrm{ng} / \mathrm{g}$ for $\mathrm{Sb}$, and $0.013 \mathrm{ng} / \mathrm{g}$ for $\mathrm{Pb}$ (20). The relatively high concentrations of these trace metals were attributed to contamination from climbers who left their waste products. These results were evaluated to determine the major sources and magnitude of heavy metal pollution and are considered an effective indicator of urban atmospheric pollution (21).

Studies on the chemical components of snow are very important since the findings can be used by policy makers to enforce reduction of anthropogenic emissions of specifically targeted and potentially toxic heavy metals (22). In addition, the results from such studies would provide social sensitivity to green environmental issues. Significant environmental pollution from a variety of trace elements due to dust storms, traffic, smelting, and burning of fossil fuel was found in Diyarbakir, Turkey. Our preliminary results have shown that snow precipitation in Diyarbakir could be a suitable matrix for receptor model studies aimed at identifying and quantifying pollution sources in SE Anatolia. In this study, we propose a simple and affordable ICP-OES methodology to complement the information obtained from urban atmospheric surveillance networks $(5,23)$.

In the literature, information on the level of trace elements deposited in snow due to dust storms is very limited. Our study was focused on determining the level of major and trace elements in snow during and after a dust storm and to evaluate the levels of pollution.

\section{EXPERIMENTAL}

\section{Instrumentation}

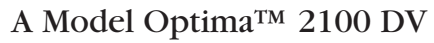
inductively coupled plasma optical emission spectrometer (ICP-OES) (PerkinElmer, Shelton, CT, USA) was used for the determination of $\mathrm{Al}$, As, Cd, Co, Cr, Cu, Fe, Mn, Mo, $\mathrm{Ni}, \mathrm{Pb}, \mathrm{Sb}, \mathrm{Se}, \mathrm{Sn}$, and $\mathrm{Zn}$ in snow samples. The instrumental operating parameters are listed in Table I. All of the procedures, from sampling to analysis, were applied to the blanks in order to evaluate any metal contamination during the analytical procedure (24-32). The blank was simultaneously prepared and all procedures were applied before measurements. The most sensitive lines without spectral interferences in the sample matrix were used for the analysis.

\section{Reagents \\ $\mathrm{HNO}_{3}$ (65\%), $\mathrm{HF}$ (48\%), and $\mathrm{HCl}$ (37.5\%) were of analytical reagent grade (E. Merck, Darmstadt, Ger-}

\section{Atomic Mpectroscopy \\ 1 Vol. 34(2), March/April 2013}

many). Distilled water was further purified with a Milli-Q ${ }^{\mathrm{TM}}$ system (Millipore Corporation, USA) and used for all of the experiments.

\section{Sampling}

Snow samples were collected from the urban areas of Diyarbakir, located in SE Anatolia, Turkey $\left(40^{\circ} 14^{\prime} \mathrm{N}, 37^{\circ} 55^{\prime} \mathrm{E}, 670 \mathrm{~m}\right.$ above sea level), a metropolitan city with a population of about two million. A total of 21 snow samples were collected during and immediately after a snowfall at seven sites on February 28, 2012. Seven sampling sites, five near the city center and two in rural areas, were selected and the local contamination from nearby emissions due to antrophogenic activities, roads, villages, trees, or exposed rocks was taken into consideration. The distance between the two sampling sites was around $5 \mathrm{~km}$.

TABLE I

ICP-OES Instrumental Operating Conditions

\begin{tabular}{ll}
\hline Instrumentation & PerkinElmer Optima ${ }^{\mathrm{TM}} 2100 \mathrm{DV}$ \\
RF power & $1450 \mathrm{~W}$ \\
Plasma gas flow rate & $15 \mathrm{~L} \mathrm{~min}^{-1}$ \\
Auxiliary gas flow rate & $0.2 \mathrm{~L} \mathrm{~min}^{-1}$ \\
Nebulizer gas flow rate & $0.8 \mathrm{~L} \mathrm{~min}^{-1}$ \\
Sample flow rate & $1.5 \mathrm{~L} \mathrm{~min}^{-1}$ \\
View mode & Axial \\
Read & Peak area \\
Source equilibration time & $15 \mathrm{~s}$ \\
Read delay & $50 \mathrm{~s}$ \\
Replicates & 3 \\
Background correction & $2-$ point (manual point correction) \\
Spray chamber & Scott type spray chamber \\
Nebulizer & Cross-Flow GemTip \\
Detector & SCD \\
Purge gas & Nitrogen \\
Shear gas & Air \\
Plasma gas & Argon \\
\hline
\end{tabular}




\section{Samples and Sample Pretreatment}

The snow samples were evaporated and the residue was digested in a Berghof MWS3 microwave oven (Berghof, USA) prior to instrumental analysis. The microwave oven program suggested by the manufacturer was modified by adding a 5.0-mL mixture of $\mathrm{HF} / \mathrm{HNO}_{3} / \mathrm{HCl}(2: 4: 1)$ to the residue before transferring it to the microwave vessel. Then, it was digested in the microwave oven using the conditions listed in Table II.

\section{Reference Materials}

The analytical results using a certified reference material (CRM) are listed in Table III. CRM EnviroMAT Waste Water, Low (EU-L-2) SC5181302 (obtained from SCP SCIENCE, Canada) was used to check the accuracy of the proposed method. The procedure used for the snow samples was also applied to this CRM. As can be seen from Table III, the concentrations of Al, As, Cd, Co, Cr, Cu, Fe, Mn, Mo, Ni, $\mathrm{Pb}, \mathrm{Sb}, \mathrm{Se}$, and $\mathrm{Zn}$ were in good agreement with the certified values of the CRM.

TABLE II

Operating Conditions for the Two-Stage Digestion in the Microwave Oven

\begin{tabular}{lrrr}
\hline Step 1 & & & \\
\hline Temp. $\left({ }^{\circ} \mathrm{C}\right)$ & 140 & 160 & 190 \\
$\mathrm{t}_{\mathrm{a}}(\min )^{\mathrm{a}}$ & 5 & 3 & 5 \\
$\mathrm{t}_{\mathrm{b}}(\min )^{\mathrm{b}}$ & 5 & 10 & 20 \\
\hline
\end{tabular}

\begin{tabular}{lrr} 
Step 2 & \\
\hline Temp. $\left({ }^{\circ} \mathrm{C}\right)$ & 160 & 100 \\
$\mathrm{t}_{\mathrm{a}}(\min )^{\mathrm{a}}$ & 3 & 1 \\
$\mathrm{t}_{\mathrm{b}}(\min )^{\mathrm{b}}$ & 15 & 15
\end{tabular}

\footnotetext{
a Waiting time at desired temperature.

b Time between the two successive temperatures.
}

\section{RESULTS AND DISCUSSION}

Diyarbakir, which is the largest populated area in SE Anatolia of Turkey, has a major air pollution problem because of topography, negative meteorological factors, increase in population growth, and use of poor quality fuel for heating (7).

In general, most of the heavy metals and persistent organic compounds come from environmental and anthropogenic sources, which are transported over long distances by air and water. These compounds are toxic and present in the ecosystems all over the world. The toxic trace elements in the different

\section{TABLE III}

Accuracy Assessment Through the Analysis of CRM EnviroMAT Waste Water, Low (EU-L-2) SC5181302

\begin{tabular}{ccc}
\hline $\begin{array}{c}\text { Ele- } \\
\text { ment }\end{array}$ & $\begin{array}{c}\text { Confidence Interval } \\
\text { Certified } \\
(\mathrm{mg} / \mathrm{L})\end{array}$ & $\begin{array}{c}\text { Measured } \\
(\mathrm{mg} / \mathrm{L})\end{array}$ \\
\hline $\mathrm{Al}$ & $0.048-0.056$ & $0.049-0.054$ \\
$\mathrm{As}$ & $0.078-0.083$ & $0.077-0.081$ \\
$\mathrm{Cd}$ & $0.022-0.024$ & $0.022-0.025$ \\
$\mathrm{Co}$ & $0.080-0.082$ & $0.079-0.084$ \\
$\mathrm{Cr}$ & $0.059-0.061$ & $0.058-0.060$ \\
$\mathrm{Cu}$ & $0.101-0.109$ & $0.099-0.104$ \\
$\mathrm{Fe}$ & $0.048-0.054$ & $0.045-0.049$ \\
$\mathrm{Mn}$ & $0.117-0.122$ & $0.119-0.121$ \\
$\mathrm{Mo}$ & $0.037-0.042$ & $0.034-0.043$ \\
$\mathrm{Ni}$ & $0.080-0.084$ & $0.081-0.085$ \\
$\mathrm{~Pb}$ & $0.040-0.043$ & $0.038-0.042$ \\
$\mathrm{Sb}$ & $0.018-0.020$ & $0.016-0.019$ \\
$\mathrm{Se}$ & $0.026-0.028$ & $0.024-0.027$ \\
$\mathrm{Zn}$ & $0.021-0.026$ & $0.021-0.024$ \\
\hline
\end{tabular}

The Confidence Interval was calculated using the 95\% Confidence Level (equivalent to $2 \sigma$ ) with the following formula:

$\mathrm{x} \pm(\mathrm{ts} / \sqrt{ } \mathrm{n})$

where

$\mathrm{n}$ : Number of data

$\mathrm{s}$ : Standard deviation of the average

t: Factor for Student's $t$-test

$\mathrm{x}$ : Consensus value types of dust found in an urban environment are most highly concentrated in suspended particulate matter. Snow is considered to be an ideal matrix to observe deposition from the atmosphere and can be easily and inexpensively sampled in well-defined increments $(7,15,33)$.

A simple and effective ICP-OES method is presented for assessing the atmospheric pollution in urban areas. Snow samples from seven sites (21 samples), located in and around the urban areas of Diyarbakir, Turkey, were collected simultaneously during and after a dust storm on February 28, 2012. The mean concentrations of $\mathrm{Al}$, As, Cd, Co, $\mathrm{Cr}, \mathrm{Cu}, \mathrm{Fe}, \mathrm{Mn}, \mathrm{Mo}, \mathrm{Ni}, \mathrm{Pb}, \mathrm{Sb}, \mathrm{Se}$, $\mathrm{Sn}$, and $\mathrm{Zn}$ in the snow samples, together with the $\mathrm{pH}$ of melted snow samples from different locations of the city, are given as a mean of three replicates in Table IV.

For calculating the detection limits, blank measurements were taken into consideration. Thus, the blank sample was analyzed 10 times and the standard deviation of the results was calculated using $3 \mathrm{~s} / \mathrm{m}$ (slope of the calibration plot) (34).

Table IV lists the concentrations of the elements found in snow from Diyarbakir. As expected, the $\mathrm{Al}$ and Fe oxides are the major components and present at high concentrations. It has been reported (5) that the geological structure of soil in arid and semi-arid regions of the Middle East are the major sources of mineral dust from the atmosphere and contain trace elements such as Fe and $\mathrm{Al}$. In this study, the elements As, Mo, Se, and $\mathrm{Sb}$ were not detected in any of the snow samples, while $\mathrm{Cd}, \mathrm{Co}, \mathrm{Cu}$, $\mathrm{Mn}, \mathrm{Ni}, \mathrm{Pb}, \mathrm{Zn}, \mathrm{Cr}$, and $\mathrm{Sn}$ were present at higher and wider concentrations, and high elemental concentrations were found mainly for $\mathrm{Fe}, \mathrm{Al}$, and $\mathrm{Mn}$. The mean concentrations (see Table IV) for these elements in the snow samples were 
$22688 \pm 52,13245 \pm 34$, and $212.40 \pm 1.39 \mu \mathrm{g} / \mathrm{kg}$, respectively. All other elements were found at lower concentrations.

As can be seen in Table IV, the average heavy metal concentrations in the snow samples from within the city were in the order of $\mathrm{Fe}>\mathrm{Al}>\mathrm{Cr}>\mathrm{Mn}>\mathrm{Zn}>\mathrm{Cu}>\mathrm{Co}>\mathrm{Ni}>\mathrm{Sn}>$ $\mathrm{Pb}>\mathrm{Cd}$. It can, therefore, be concluded that dust storms are the main reason for this high metal concentration and result from the major synoptic systems that bring desert dust from Saudi Arabia and the Sahara Desert to the Anatolia region (5). It was found that the mean concentrations of $\mathrm{Pb}, \mathrm{Cd}, \mathrm{Cu}$, $\mathrm{Zn}, \mathrm{Mo}$, and $\mathrm{Sb}$ in the snow samples from the Anatolia regions were smiliar to the metal concentrations reported for Cerro Colorado and Nevados de Chillán (Chile) (15), while the concentrations of $\mathrm{Ni}, \mathrm{Mn}$, $\mathrm{Cd}$. Cr, and Co were higher than in
Anatolia. As suggested by Meresova et al. (11), the organic and inorganic chemical compositions, physical characteristics, and concentrations of these elements in dust particles should be investigated further to help protect human health. In addition, chemical speciation data are needed for species that are extremly toxic, such as $\mathrm{As}^{3+}$, in comparison to the non-toxic forms, such as $\mathrm{As}^{5+}$.

Atmospheric aerosols consist of particles that are of natural and anthropogenic origin. It has now been well established that elements obtained from natural sources are generally found in coarse particles, while elements emitted from anthropogenic activities are associated with fine particles (35). Generally, air-borne particulate matter can give information about the degree of atmospheric pollution. Canepari et al. (36) also advise that chemical characterization of partic-

TABLE IV

Analytical Wavelengths ( $\lambda$ ), Detection Limits (LOD), and Average Concentration of the Chemical Elements in Surface Snow During and After Dust Storm in Diyarbakir, Turkey

\begin{tabular}{lcll}
\hline Elements & $\begin{array}{c}\lambda \\
(\mathrm{nm})\end{array}$ & $\begin{array}{c}\text { LOD } \\
(\mu \mathrm{g} / \mathrm{kg})\end{array}$ & $\begin{array}{c}\text { Snow } \\
\text { Mean } \pm \mathrm{SD}(\mu \mathrm{g} / \mathrm{kg})\end{array}$ \\
\hline $\mathrm{Al}$ & 396.153 & 5.0 & $13245 \pm 34$ \\
$\mathrm{As}$ & 193.696 & 10.0 & $<10.0$ \\
$\mathrm{Cd}$ & 228.802 & 6.0 & $7.56 \pm 0.22$ \\
$\mathrm{Co}$ & 228.616 & 5.0 & $12.48 \pm 1.76$ \\
$\mathrm{Cr}$ & 267.716 & 5.0 & $431 \pm 5$ \\
$\mathrm{Cu}$ & 327.393 & 4.0 & $22.40 \pm 2.13$ \\
$\mathrm{Fe}$ & 238.204 & 5.0 & $22688 \pm 52$ \\
$\mathrm{Mn}$ & 257.610 & 5.0 & $212.40 \pm 1.39$ \\
$\mathrm{Mo}$ & 202.031 & 5.0 & $<5.0$ \\
$\mathrm{Ni}$ & 231.610 & 5.0 & $11.80 \pm 0.97$ \\
$\mathrm{~Pb}$ & 220.353 & 6.0 & $12.34 \pm 0.68$ \\
$\mathrm{Sb}$ & 206.836 & 10.0 & $<10.0$ \\
$\mathrm{Se}$ & 196.026 & 10.0 & $<10.0$ \\
$\mathrm{Sn}$ & 189.927 & 5.0 & $6.14 \pm 0.31$ \\
$\mathrm{Zn}$ & 206.200 & 5.0 & $22.87 \pm 2.67$ \\
\hline $\mathrm{pH}$ & 7.36 & &
\end{tabular}

S. D.: Standard deviation

LOD: Limit od Detection

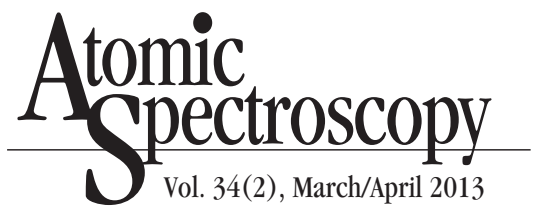

ulate matter not only provides interesting data for the evaluation of its impact on human health and environmental pollution, but also for the identification of specific emission sources. In addition, atmospheric pollution with regard to heavy metals is really a global problem due to their transport by wind and other forces of nature, such as dust storms (18).

\section{CONCLUSION}

The concentrations of $\mathrm{Al}, \mathrm{As}, \mathrm{Cd}$, $\mathrm{Co}, \mathrm{Cr}, \mathrm{Cu}, \mathrm{Fe}, \mathrm{Mn}, \mathrm{Mo}, \mathrm{Ni}, \mathrm{Pb}, \mathrm{Sb}$, $\mathrm{Se}, \mathrm{Sn}$, and $\mathrm{Zn}$ were determined by inductively coupled plasma optical emission spectrometry (ICP-OES) in snow samples collected during and after a dust storm in and near the city of Diyarbakir, SE Anatolia, Turkey, on February 28, 2012. This study shows that the levels of major and toxic metals in the snow samples were higher than reported previously.

From the results presented here, it can be stated that the analysis of snow can provide important information on the degree of atmospheric pollution. For that reason, further attention should be focused on this type of analysis to avoid potential health risks. By considering the residence time and mobility of dust particles precipitated in snow due to meteorological conditions such as humiditiy, wind speed, and precipitation, timely advice could be provided to the local population and be advised to abstain from eating snow since it is polluted and a potential health risk. It is, therefore, highly important that further investigations be focused on global pollution and the toxic effects of air-borne particulate matter. In addition, novel and more sensitive analytical methods need to be developed to monitor trace level metals in the small fractions of dust precipitated in snow samples.

Received November 5, 2012. 


\section{REFERENCES}

1. S. Tokalioglu and S. Kartal, Atmos. Environ. 40, 2797 (2006).

2. A. Turkum, B. Pekey, H. Pekey, and G. Tuncel, Atmos. Res. 89, 306 (2008).

3. G. H. Gullu, I. Olmez, and G. Tuncel, Spectrochim. Acta B, 55, 1135 (2000).

4. D.G. Kaskaoutis, H.D. Kambezidis, P.T. Nastos, and P.G. Kosmopoulos, Atmos. Environ. 42, 6884 (2008).

5. F. Aydin, I. Aydin, S. Erdoğan, O. Akba, B. Isik, and C. Hamamci, Pol. J. Environ. Stud. 21, 533. (2012)

6. H. R. Anderson, Atmos. Environ. 43, 142 (2009).

7. C. Hamamci, B. Gumgum, O. Akba, and S. Erdogan, Fresenius Environ. Bull. 6, 430 (1997).

8. A. Baysal, O. Akba, M. Merdivan, C. Hamamci, and B. Gumgum, Ann. Chim. 92, 1127 (2002).

9. S. Canepari, C. Perrino, M.L. Astolfi, M. Catrambone, and D. Perret, Talanta 77, 1821 (2009).

10. B. Isık, C. Hamamci, and R. Isık, Asian. J. Chem. 18, 1433 (2006).

11. J. Meresova, M. Florek, K. Holy, M. Jeskovsky, I. Sykora, M.V. Frontasyeva, S.S. Pavlov, and M. Bujdos, Atmos. Environ. 42, 8079 (2008).

12. M.V. Vasic, A. Mihailovic, U. Kozmidis-Luburic, T. Nemes, J. Ninkov, T. Zeremski-Skoric, and B. Antic, Chemosphere 86, 585 (2012).

13. S.Y. Karakas, and S.G. Tuncel, Intern. J. Environ. Anal. Chem. 66, 137 (1997).

14. J. Fengqing, Z. Cheng, W. Wenshou, and O. Abe, Atmos. Environ. 36, 4941 (2002).

15. F. Cereceda-Balic, M.R. PalomoMarín, E. Bernalte, V. Vidal, J. Christie, X. Fadic, J.L. Guevara, C. Miro, and E. Pinilla Gil, Atmos. Environ. 47, 51 (2012).

16. L. Krnavek, W. R. Simpson, D. Carlson, F. Domine, T.A.
Douglas, and M. Sturm, Atmos. Environ. 50, 349 (2012).

17. F. Aydin, A. Saydut, B. Gunduz, I. Aydin, and C. Hamamci, Clean Soil, Air, Water 40, 444 (2012).

18. F. A.M. Planchon, C. F. Boutron, C. Barbante, G. Cozzi, V. Gaspari, E.W. Wol, C.P. Ferrari, and P. Cescon, Earth. Planet. Sc. Lett. 200, 207 (2002).

19. F.A.M. Planchon, C.F. Boutron, C. Barbante, E.W. Wolff, G. Cozzi, V. Gaspari, C P. Ferrari, and P. Cescon, Anal. Chim. Acta. 450, 193 (2001).

20. Q.G. Zhang, S. C.Kang, Z.Y.Cong, S.G. Hou, and Y.Q. Liu, Chinese Sci. Bull. 53, 289 (2008).

21. A. Elik, Intern. J. Environ. Anal. Chem. 82, 37 (2002).

22. P. Gabrielli, G. Cozzi, S. Torcini, P. Cescon, and C. Barbante, Chemosphere 72, 1504 (2008).

23. S. Erdogan, A. Baysal, O. Akba, M. Merdivan, and C. Hamamci, Asian J. Chem. 19, 1703 (2007).

24. I. Aydin, F. Aydin, and C. Hamamci, Fuel 95, 481 (2012).

25. I. Aydin, F. Aydin, and C. Hamamci, Microchem. J. 108, 64 (2013).

26. I. Aydin, F. Aydin, A. Saydut, E.G. Bakirdere, and C. Hamamci, Microchem. J. 96, 247 (2010).

27. O. Akba, A. Baysal, C. Hamamci, M. Merdivan and B. Gumgum, Asian J. Chem. 17, 1518 (2005).

28. I. Aydin, F. Aydin, and C. Hamamci, Water Environ. Res. 82 (11), 2265 (2010)

29. M. Yaman, A. Sasmaz, G. Kaya, M. Ince, N. M. Karaaslan, C. Ozcan and S. Akkus, At. Spectrosc. 32(5), 182 (2011).

30. F. Aydin, A. Saydut, I. Aydin, and C. Hamamci, At. Spectrosc. 32 (5), 194 (2011).

31. B. Gunduz, F. Aydin, I. Aydin, and C. Hamamci, Microchem. J. 98 (1), 72 (2011).

32. M.Z. Duz, K.S. Celik, I. Aydin, S. Erdogan, F. Aydin, and C. Hamamci, At. Spectrosc. 33 (3), 78 (2012)

33. R. Zhang, Z. Han, Z. Shen, and
J. Cao, Adv. Atmos. Sci. 25, 89 (2008).

34. I. Aydin, U. Yuksel, R. Guzel, B. Ziyadanogullari, and F. Aydin, At. Spectrosc. 31(2), 67 (2010).

35. A. Srivastava, and V.K. Jain, Chemosphere 68, 579 (2007).

36. S. Canepari, A. Pietrodangelo, C. Perrino, M. L. Astolfi, and M.L. Marzo, Atmos. Environ. 43, 4754 (2009). 